\title{
Enhancing Native Grass Productivity by Cocultivating With Endophyte-Laden Calli
}

\author{
M. E. Lucero, ${ }^{1}$ J. R. Barrow, ${ }^{2}$ P. Osuna, ${ }^{3}$ I. Reyes, ${ }^{4}$ and S. E. Duke ${ }^{5}$ \\ Authors are ${ }^{1}$ Research Molecular Biologist and ${ }^{2}$ Research Plant Geneticist, US Department of Agriculture-Agricultural Research Service, Jornada \\ Experimental Range, Box 30003 MSC 3JER, 2995 Knox Street, Las Cruces, NM 88003-8003, USA; ${ }^{3}$ Professor-Investigador, Departamento de Ciencias \\ Básicas, Universidad Autonoma de Cd. Juarez, Zona Pronaf Cd. Juarez, Chibuahua, CP 32310, Mexico; ${ }^{4}$ PhD Candidate, Department of Plant and \\ Environmental Sciences, New Mexico State University, Box 30003 MSC 3Q, Las Cruces, NM 88003-8003, USA; and ${ }^{5}$ Statistician, US Department of \\ Agriculture-Agricultural Research Service, Southern Plains Area Research Center, 2881 F\&B Road, College Station, TX 77845, USA.
}

\begin{abstract}
The influence native endophytes have on grass establishment and productivity was evaluated by cocultivating Bouteloua eriopoda (Torr.) Torr. (black grama) or Sporobolus cryptandrus (Torr.) Gray (sand dropseed) seedlings with endophyte-laden calli from three of four native grass and shrub species: Atriplex canescens (Pursh) Nutt. (fourwing saltbush), S. cryptandrus, Sporobolus airoides (Torr.) Torr. (alkali sacaton), and B. eriopoda in vitro. Following cocultivation, grass seedlings were hardened and transferred to three replicate field plots, each containing 16 grass plants of a single species that had been cocultivated with a single callus species. Plant establishment rates, heights, crown diameters, aboveground biomass, seed yields, and seed quality were compared. In B. eriopoda (black grama), significant increases in plant biomass were not observed. However, early plant heights and crown diameters, establishment rates, and stolon production were higher in some callus treatments. In $S$. cryptandrus (sand dropseed), all variables were positively influenced by one or more of the endophyte treatments. Biomass increases ranged from 2.5- to threefold over untreated plants, and harvested seed increased 5.9-fold in plants treated with endophytes from $A$. canescens (fourwing saltbush). Seed quality, determined by purity, germination rates, and tetrazolium assays, did not differ across endophyte treatments for either grass. There is evidence that endophyte transfer is responsible for the altered vigor of treated plants.
\end{abstract}

\section{Resumen}

Se evaluó la influencia que los endófitos nativos tienen en el establecimiento y productividad de los zacates al co-cultivar plántulas de Bouteloua eriopoda (Torr.) Torr. ("black grama”) o Sporobolus cryptandrus (Torr.) Gray ("sand dropseed”) con callos conteniendo de endofitos de tres de cuatro especies nativas de zacates y arbustos: Atriplex canescens (Pursh) Nutt. ("fourwing saltbush"), S. cryptandrus, Sporobolus airoides (Torr.) Torr. (“alkali sacaton”) y B. eriopoda in-vitro. Después del co-cultivo, las plántulas de los zacates fueron aclimatadas y transferidas a campo con tres repeticiones, cada parcela conteniendo 16 plántulas de una especie de zacate, que habían sido co-cultivadas con un callo de una sola especie. Se compararon las tasas de establecimiento, alturas, diámetros de corona, biomasa aérea y rendimiento de semilla y su calidad. En B. eriopoda ("black grama") no se observaron incrementos significativos de la biomasa vegetal. Sin embargo, la altura y diámetro de la corona en etapas tempranas, las tasas de establecimiento y la producción de estolones fueron mayores en algunos de los tratamientos con callos. En S. cryptandrus ("sand dropseed"), todas las variables fueron influenciadas positivamente por uno o mas de los tratamientos de endófitos. Los incrementos de biomasa estuvieron en un rango de 2.5 a 3 veces más de lo producido por las plantas sin tratar y la semilla cosechada fue 5.9 veces más en las plantas tratadas con endofitos provenientes de A. canescens ("fourwing saltbush"). La calidad de la semilla, determinada por la pureza, tasa de germinación y ensayos con tetrazolium, no difirió entre tratamientos de endófitas en ninguna de las especies de zacates. Hay evidencia de que la transferencia endófita es responsable del vigor alterado de las plantas tratadas.

Key Words: Atriplex canescens, Bouteloua eriopoda, Sporobolus airoides, Sporobolus cryptandrus

\section{INTRODUCTION}

In recent years, rapidly growing pools of evidence suggest that many, if not all, plants are supported by vast communities of endophytic microbes (Vandenkoornhuyse et al. 2002; Pirttila et al. 2003; Ganley et al. 2004; Lucero et al. 2006). In some cases, these microbes are believed to assist plant hosts in nutrient assimilation (Barrow and Osuna 2002; Govindarajulu et al. 2005), herbivore defense (Clay et al. 1985; Clay and Schardl 2002; Bultman and Bell 2003), and overall growth (Lucero et

Correspondence: M. E. Lucero, Jornada Experimental Range, USDA ARS, 2995 Knox St, Las Cruces, NM 88003-8003, USA. Email: malucero@nmsu.edu

Manuscript received 2 November 2006; manuscript accepted 8 October 2007. al. 2006). Several targeted studies have indicated the potential of systemic endophytes to significantly increase productivity of associated plant hosts (Redman et al. 2002; Ernst et al. 2003; Obledo et al. 2003; Schardl et al. 2004; Waller et al. 2005). These studies suggest alteration of fungal endophyte populations to increase plant productivity may be easier and more effective than altering host plant genetics through breeding or engineering. The diversity of fungal endophytes that inhabit plants may serve as an untapped reservoir of tools for improving plant materials used for reseeding efforts.

Recent experiments in which uncultured endophytes from Bouteloua eriopoda (Torr.) Torr. (black grama grass) and Atriplex canescens (Pursh) Nutt (fourwing saltbush) were transferred to novel host grasses via callus cultures demonstrated 
potential for endophytes to increase root and shoot production in vitro (Lucero et al. 2006). Because these endophytes are systemically associated with callus tissue and whole plants in vitro, and because they were present in the seeds from which the in vitro cultures are established, these endophytes are believed to be passed from parent plants to progeny, much like the betterdescribed endophytes associated with cool-season fescues (Schardl et al. 2004; Clay et al. 2005). It was not known if the observed differences would persist in field-cultivated plants, where influences of external microflora would be more profound.

In the current study, germinating seeds from Sporobolus cryptandrus (Torr.) Torr. (sand dropseed) and black grama were cocultivated with endophyte-laden, in vitro callus cultures from three of four Chihuahuan desert plant species: sand dropseed, Sporobolus airoides (Torr.) Torr. (alkali sacaton), fourwing saltbush, and black grama. Germinating seeds of the two grasses were not cocultured with endophyte-laden callus from that same species. For convenience, the endophyte-laden calli from these plant species will be referred to as SPCRe, SPAIe, ATCAe, and BOERe, respectively. It was presumed that cocultivation would result in migration of endophytes from the callus to the developing seedling.

\section{METHODS}

\section{Callus Initiation}

Endophyte-laden callus cultures of fourwing saltbush and black grama came from callus lines established by Barrow et al. (2004). Endophyte consortia, which are largely comprised of fungi, have been described in each of these lines (Lucero et al. 2006). Callus cultures of sand dropseed and alkali sacaton were established from seeds that had been surface-disinfested by soaking for $10 \mathrm{~min}$ in $50 \%$ ethanol, followed by $25 \mathrm{~min}$ in $50 \%$ bleach. Seeds were rinsed three times in sterile water, and allowed to germinate on Murashigie and Skoog (MS) medium (Murashige and Skoog 1962). Shoot apexes were dissected from sand dropseed and alkali sacaton seedlings ( $15 \mathrm{~d}$ old $)$ and transferred to fresh plates of MS supplemented with $1 \mathrm{mg} \cdot \mathrm{L}^{-1}$ 2,4-dichlorophenoxyacetic acid for callus induction. The calluses were maintained with monthly subcultures to fresh MS medium containing the same growthregulator concentration. Prior to seed inoculation, callus was transferred to hormone-free MS medium and maintained for $30 \mathrm{~d}$ in order to prevent residual artificial growth regulators from transferring to inoculated seedlings.

\section{Cocultivation}

Sand dropseed and black grama seeds were obtained from Plants of the Southwest (Santa Fe, NM) and surface-disinfested as described above. Disinfested seeds were placed on MS media and incubated at $26^{\circ} \mathrm{C}$ in a growth chamber receiving light over a $12-$ $\mathrm{h} \cdot \mathrm{d}^{-1}$ photoperiod. Light in the range of 400 to $700 \mathrm{~nm}$ was measured as photosynthetic photon flux at $151 \mu \mathrm{mol} \cdot \mathrm{m}^{-2}$. $\mathrm{s}^{-1}$ using a quantum light meter (Spectrum Technologies, Inc, Plainfield, IL). Upon emergence of the radicle, seedlings to be cocultivated were aseptically transferred to callus cultures, placing the germinating seedling in direct contact with the callus for $20 \mathrm{~d}$. Groups of seedlings were cocultivated with three of the four callus species. Sand dropseed seedlings were inoculated with ATCAe, BOERe, or SPAIe. Black grama was inoculated with
ATCAe, SPAIe, or SPCRe. Control plants were not cocultivated with any callus species, but were maintained aseptically on hormone-free MS medium in the same growth chamber as those plantlets that were being cocultivated.

\section{Seedling Establishment}

Seedlings were transferred to $5.1-\mathrm{cm}$ peat pots containing a mixture of $50 \%$ commercial potting soil and $50 \%$ soil collected from the field site, located on the Jornada Experimental Range in southern New Mexico. Seedlings were allowed to establish in the growth chamber described above for $20 \mathrm{~d}$, then transferred to a heated greenhouse for $45 \mathrm{~d}$. During this time, seedlings were irrigated with tap water as needed.

\section{Site Description}

The field site used for this study was located at the Jornada Experimental Range Headquarters near Las Cruces, New Mexico. GPS coordinates taken from the northern edge of the test plot are lat $32^{\circ} 36^{\prime} 59^{\prime \prime} \mathrm{N}$, long $106^{\circ} 44^{\prime} 29^{\prime \prime} \mathrm{W}$. Total precipitation per year on the site averages $245 \mathrm{~mm}$.

\section{Field Site Planting and Maintenance}

The field site was prepared by fencing the area to exclude large and small mammals and tilled to a depth of $15 \mathrm{~cm}$. Parallel drip irrigation lines and emitters were gridded on 46- $\mathrm{cm}$ centers. Organic matter was supplemented with $1.415 \mathrm{~m}^{3}$ of steer manure (Grow King; Western Organics Inc, Tempe, AZ) uniformly incorporated into the tilled soil, and glyphosate herbicide (Roundup ${ }^{\mathrm{TM}}$; Monsanto, St. Louis, MO) was applied according to manufacturer's instructions 2 wk prior to planting. Seedling flats were moved to the field site and maintained in peat pots for $1 \mathrm{wk}$ in order to harden prior to transplanting. Hardened seedlings were planted by hand on $46-\mathrm{cm}$ centers with one water emitter next to each plant and 16 plants per 2.5$\mathrm{m}^{2}$ plot. Edge effects were reduced by placing two additional rows of grasses around the entire plot. Each plot had only one combination of grass species and cocultivated callus treatment. Three replicate plots were established for each combination.

Low summer rainfall and high temperatures can prevent successful establishment of native grasses. To ensure establishment of all treatments, water was applied once a week for 45 min (approximately $1 \mathrm{~L} \cdot$ plant $^{-1}$ ). Weeds were removed manually with a scuffle hoe or by hand as required throughout the growth season.

\section{Plant Establishment}

Initial estimates of plant establishment were made in July 2005, $8 \mathrm{wk}$ after transplanting to the field. Plants lacking visible green tissue were assigned a value of 0 , indicating initial establishment failed. All others were assigned an establishment value of 1 . Long-term establishment was determined by repeating this procedure in October 2005 and in May 2006. Plants that exhibited no aboveground green tissue throughout this time were presumed dead.

\section{Plant Growth Measurements}

Growth measurements were made in early and late season by measuring crown diameter and height of the tallest tiller for 
each plant. Early growth was evaluated in July, 8 wk after planting. Late growth was measured in October, 22 wk after planting. In October, aboveground biomass was harvested by removing all plant material greater than $1 \mathrm{~cm}$ above the crown. Plant material was immediately stored in brown paper bags and transported to the laboratory (approximately $1 \mathrm{~h}$ travel time). After collecting seeds and counting numbers of stolons, plant material was dried at $60^{\circ} \mathrm{C}$. Plants were considered dry when an additional hour in the oven produced no change in sample weight. Seeds were weighed fresh and analyzed independently from remaining aboveground biomass.

\section{Reproductive Potential}

Seeds were harvested from field-cultivated plants and separated from shoots by clipping seed heads manually, then shaking seed heads in a Ro-Tap ${ }^{\circledR}$ RX-29 mechanical sieve (W.S. Tyler, Mentor, OH). Total seed harvested per 16 plant replicate was recorded in grams. Total live seed and seed quality assays were conducted independently at the New Mexico Department of Agriculture State Seed Laboratory.

Sand dropseed seeds were analyzed according to the Association of Official Seed Analysts (AOSA) Rules for Testing Seeds (1990). Black grama, which is not covered by AOSA rules, was analyzed as follows: approximately $1 \mathrm{~g}$ of seed from each replication was tested for purity by manually separating seeds from plant debris and weighing resulting fractions. Germination assays utilized 400 pure seed units. Sets of 100 seeds were placed in four covered petri dishes atop unbleached blotter paper soaked in $0.2 \% \mathrm{KNO}_{3}$ solution and incubated in an alternating diurnal growth chamber at $20^{\circ} \mathrm{C}$ for $16 \mathrm{~h}$ in the dark followed by $8 \mathrm{~h}$ of light at $35^{\circ} \mathrm{C}$. This cycle was repeated for $28 \mathrm{~d}$ before counting numbers of germinated plants. Viable dormant seeds were determined for pure seed units remaining on the final day of the test. An additional 100 pure seed units were tested for dormancy using tetrazolium protocols established by the International Board of Plant Genetic Resources (Ellis et al. 1985). One untreated black grama replicate lacked 100 seeds following germination assays. For that sample, only 67 seeds were tested with tetrazolium.

\section{Statistical Analysis}

The experiment was a completely randomized design with three replicate plots of 16 plants each. The two factors of interest were the host plant species (black grama and sand dropseed) and the four callus species used as inoculants (ATCAe, BOERe, SPAIe, or SPCRe). Sand dropseed plants were inoculated with ATCAe, BOERe, or SPAIe and black grama was inoculated with ATCAe, SPAIe, or SPCRe. Uninoculated seedlings of each plant species were used as experimental controls. Because sand dropseed and black grama were not cocultivated with any type of callus, this experiment was not a complete factorial design. Therefore, each host species was analyzed separately. A multiple comparison adjustment was not applied because we only compared the three endophyte treatments to the control (three comparisons per variable). Furthermore, we were more concerned with Type II error than Type I error at this early stage of research. For specific comparisons, we maintained a Type I error rate of 0.05 (Scheiner 1993).
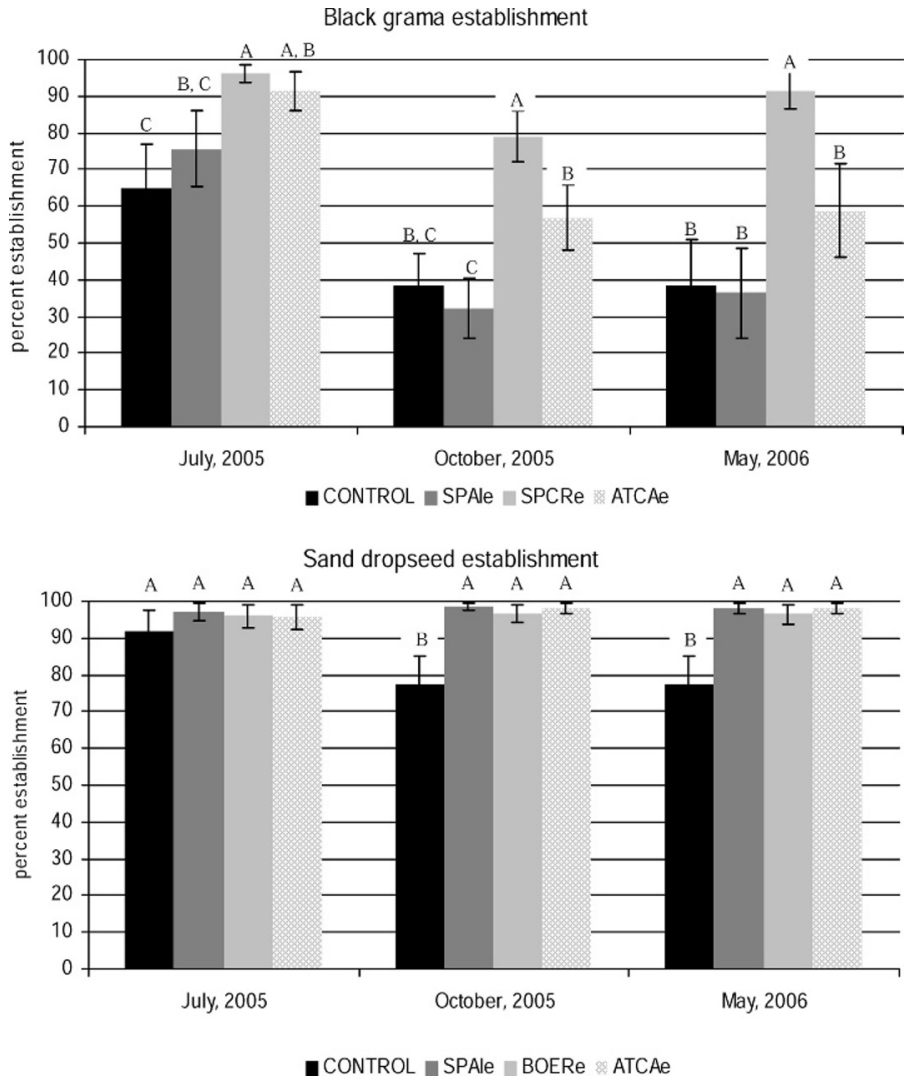

Figure 1. Establishment rates of black grama and sand dropseed transplants. Values represent the percentage of black grama and sand dropseed transplants with visible green tissue 2, 5, and 12 mo after planting. Error bars represent standard errors. Within a single timepoint, letters indicate significant differences. The increased means calculated for ATCAe-treated plants observed between October 2005 and May 2006 reflect plants that lacked green tissue in October, but were actively growing the following spring.

Statistical analysis was conducted using SAS version 9.1.3. (SAS Institute 2003) One-way analysis of variance was performed to make comparisons among treatments (different endophtye inoculants). PROC MIXED was used to analyze continuous response variables such as plant height and biomass, and PROC GLIMMIX (for generalized linear mixed models) was used to analyze discretely distributed response variables such as germination and establishment data, which were modeled with a beta distribution and logit link function (SAS Institute 2003). The 16 plants within plots were modeled as a nested variance component in a random statement.

\section{RESULTS}

\section{Black Grama Establishment}

Untreated black grama plants were difficult to establish. Despite hardening, many plants died upon transfer to the field. Only $65 \%$ of the initial transplants still exhibited green tissue 8 wk after transfer. By the end of the season, this number had decreased to approximately $38 \%$. This value remained unchanged through May 2006 (Fig. 1). However, there were differences among initial $\left(\mathrm{F}_{3,8}=3.7, P=0.0595\right)$ and final 
$\left(\mathrm{F}_{3,8}=4.71, P=0.036\right)$ establishment rates for different callus treatments. Black grama treated with SPCRe showed higher levels of establishment at $8 \mathrm{wk}(P=0.01$, July 2005) and maintained higher establishment rates throughout the study $(P=0.01$, May 2006) than the other treatments.

\section{Sand Dropseed Establishment}

Initial establishment of sand dropseed, determined $8 \mathrm{wk}$ after transplanting, exceeded $85 \%$ for all treatments (Fig. 1), and differences between treatments were not significant $\left(\mathrm{F}_{3,8}=0.6\right.$, $P=0.63)$. However, by October differences were visible $\left(\mathrm{F}_{3,8}=5.97, P=0.02\right)$. The numbers of untreated plants with visible green tissue (considered actively growing) had dropped to only $78 \%$, while the percentage of all callus-treated plants actively growing exceed $90 \%$, a value that remained constant through spring of the following year $\left(\mathrm{F}_{3,8}=4.99, P=0.03\right)$.

\section{Endophyte Influences on Plant Size, Yield, and Reproductive Potential}

Growth measurements taken in early and late season are shown in Table 1. Several callus treatments had significant effects on initial growth parameters. These included July crown diameters (for black grama, $\mathrm{F}_{3,8}=9.90, P=0.005$; for sand dropseed, $\mathrm{F}_{3,8}=7.11, P=0.01$ ) and July plant heights (for black grama, $\mathrm{F}_{3,8}=4.88, P=0.03$; for sand dropseed, $\mathrm{F}_{3,8}=7.27, P=0.01$ ). These differences were most profound in sand dropseed, where average crown diameters of BOERe- $(P=0.01)$ and SPAIe$(P=0.003)$ treated plants were twofold greater than the crown diameters of untreated plants. The only callus-plant combination that did not reveal an increase in either early plant height or early crown diameter was black grama inoculated with ATCAe $(P=0.17)$.

By late season, size differences based on crown diameter $\left(\mathrm{F}_{3,8}=0.30, P=0.80\right)$ and plant height $\left(\mathrm{F}_{3,8}=0.14, P=0.93\right)$ were no longer evident in any of the black grama treatments. However, ATCAe-treated sand dropseed plants remained taller than controls $(P=0.01)$, whereas SPAIe- $(P=0.02)$ treated plants maintained larger crown diameters. Aboveground biomass, which is a more accurate indicator of plant yield, exhibited insignificant variation across treatments for black grama $\left(\mathrm{F}_{3,8}=0.08, P=0.97\right)$. Differences observed across sand dropseed were significant, with all three callus treatments producing more aboveground biomass than untreated controls $\left(\mathrm{F}_{3,8}=7.38, P=0.01\right)$. Seed yield differences were not observed in black grama $\left(F_{3,8}=0.87, P=0.49\right)$. In sand dropseed, differences were profound $\left(\mathrm{F}_{3,8}=7.61, P=0.01\right)$. ATCAetreated plants produced a 5.9-fold increase in harvested seed $(P=0.002)$ relative to the controls (Table 1$)$. BOERe-treated sand dropseed also exhibited increased seed production $(P=0.02)$. The apparent threefold increase in seed production of SPAIe-treated plants was not significant $(P=0.09)$.

Seed quality, measured as pure live seed based on germination and purity, did not differ across treatments for black grama $\left(\mathrm{F}_{3,8}=0.64, P=0.61\right)$ and sand dropseed $\left(\mathrm{F}_{3,8}=0.77\right.$, $P=0.54)$. Tetrazolium assays indicated black grama plots yielded approximately $76 \%$ viable seed, with actual germination rates of approximately $35 \%$ (not shown). Because actual germination rates for sand dropseed were high $(>85 \%)$, tetrazolium assays were not performed.
Black grama is a stoloniferous grass, and differences in stolon production were evaluated as one determinant of reproductive potential (Fig. 2). Notably, not a single stolon was observed in the untreated plants.

\section{DISCUSSION}

In this study, two Chihuahuan desert grasses exhibited positive changes in productivity following cocultivation with endophyteladen calli from alternate plant species. Both callus and cocultivated seedling species influenced results, with the most profound changes observed in cocultivated sand dropseed. Sand dropseed responded positively to callus treatments from all three sources. Clear increases in early and late plant heights, crown diameters, aboveground biomass, and seed production were present across all callus cocultivation treatments. This is particularly interesting in the case of the reciprocal transfers. Black grama is generally less vigorous than sand dropseed, so it was initially hypothesized that the black grama callus treatment may have a detrimental effect on sand dropseed. However, even the BOERetreated sand dropseed produced larger plants with higher establishment rates and more seed than the untreated controls.

The most subtle and most variable changes were observed in black grama, where the only significant changes in plant establishment rate were observed in SPCRe-treated plants. Early in the season, both Sporobolus species used as callus sources for cocultivation in black grama produced plants that established more rapidly than controls, as indicated by differences in July plant heights and crown diameters. By October, these changes were minimal, and aboveground biomass differences between plants were negligible. Differences in seed production between treated and untreated black grama must be interpreted with caution because seeds were only harvested at a single point in time. Black grama plants flowered and produced seed throughout the season, with some seedheads visible as early as June. Stolon numbers were positively influenced by both ATCAe and SPCRe treatments, indicating potential for enhanced vegetative reproductive potential. The $>20 \%$ increase in transplant establishment of SPCRe-treated black grama, combined with an increase in stolon production, could provide a competitive advantage in rangeland environments, assuming observed changes can be replicated on unirrigated landscapes. The rapid early season growth observed in both SPCRe- and SPAIe-treated black grama plants may particularly benefit desert grasses, which are often required to utilize only brief pulses of precipitation and nutrient resources to complete flowering.

We speculate that transferred endophytes are responsible for the enhanced growth because donor callus stained positive for endophyte presence and because several cryptic endophytes have been observed in association with in vitro callus cultures (Barrow et al. 2004, 2007). Indeed, the original reason for cocultivating callus with nonhost seedlings was to attempt transfer of unculturable endophytes, which had been detected with light and electron microscopy (Barrow et al. 2004, 2007). Although initial data from molecular analysis of tomato plants cocultivated with Atriplex calli suggests that endophyte transfer does occur during cocultivation, molecular analyses on the grasses used in this study are not presently feasible. 
Table 1. Mean estimates and standard error of plant size, seed production, and aboveground biomass per plant for callus-treated and untreated native grass species. Plant species used as callus material included fourwing saltbush (Atriplex canescens, ATCAe), black grama (Bouteloua eriopoda, BOERe), alkali sacaton, (Sporobolus airoides SPAle), and sand dropseed (Sporobolus cryptandrus, (SPCRe). Control plants were not exposed to callus prior to planting. The last column (Treatment control ${ }^{-1}$ ) gives the ratio of the callus-exposed treatment to nonexposed control for each variable.

\begin{tabular}{|c|c|c|c|c|c|}
\hline Species & Variable & Endophyte treatment & Estimate $^{1}$ & Standard error & Treatment $\cdot$ control $^{-1}$ \\
\hline \multirow[t]{24}{*}{ Black grama } & \multirow[t]{4}{*}{ July crown diameter (mm) } & ATCAe & $19.3 \mathrm{bc}$ & 2.0 & 1.3 \\
\hline & & Control & $14.9 \mathrm{c}$ & 2.1 & 1.0 \\
\hline & & SPAle & $23.5 \mathrm{ba}$ & 2.0 & 1.6 \\
\hline & & SPCRe & $29.2 \mathrm{a}$ & 1.8 & 2.0 \\
\hline & \multirow[t]{4}{*}{ July plant height (mm) } & ATCAe & $111.6 \mathrm{~b}$ & 11.3 & 0.9 \\
\hline & & Control & 126.7 b & 11.6 & 1.0 \\
\hline & & SPAle & 145.6 ba & 11.0 & 1.2 \\
\hline & & SPCRe & $167.4 \mathrm{a}$ & 10.5 & 1.3 \\
\hline & \multirow[t]{4}{*}{ October crown diameter (mm) } & ATCAe & $33.6 \mathrm{a}$ & 6.6 & 1.0 \\
\hline & & Control & $32.9 \mathrm{a}$ & 6.9 & 1.0 \\
\hline & & SPAle & $38.2 \mathrm{a}$ & 7.2 & 1.2 \\
\hline & & SPCRe & $40.4 \mathrm{a}$ & 6.2 & 1.2 \\
\hline & \multirow[t]{4}{*}{ October plant height (mm) } & ATCAe & $346.3 a$ & 52.7 & 0.9 \\
\hline & & Control & $389.4 \mathrm{a}$ & 54.4 & 1.0 \\
\hline & & SPAle & $349.4 \mathrm{a}$ & 56.4 & 0.9 \\
\hline & & SPCRe & $351.5 \mathrm{a}$ & 49.8 & 0.9 \\
\hline & \multirow[t]{4}{*}{ Harvested seed $(\mathrm{g})$} & ATCAe & $3.7 \mathrm{a}$ & 2.4 & 1.0 \\
\hline & & Control & $3.7 \mathrm{a}$ & 2.4 & 1.0 \\
\hline & & SPAle & $1.9 \mathrm{a}$ & 2.4 & 0.5 \\
\hline & & SPCRe & $7.2 \mathrm{a}$ & 2.4 & 2.0 \\
\hline & \multirow[t]{4}{*}{ Average aboveground biomass $\left(\mathrm{g} \cdot\right.$ plant $\left.^{-1}\right)$} & ATCAe & $6.6 a$ & 2.8 & 0.9 \\
\hline & & Control & $7.6 \mathrm{a}$ & 2.8 & 1.0 \\
\hline & & SPAle & $7.5 \mathrm{a}$ & 2.8 & 1.0 \\
\hline & & SPCRe & $8.5 \mathrm{a}$ & 2.8 & 1.1 \\
\hline \multirow[t]{24}{*}{ Sand dropseed } & \multirow[t]{4}{*}{ July crown diameter (mm) } & ATCAe & $36.8 \mathrm{bc}$ & 4.8 & 1.6 \\
\hline & & BOERe & $46.4 \mathrm{ba}$ & 4.8 & 2.0 \\
\hline & & Control & $23.3 \mathrm{c}$ & 4.9 & 1.0 \\
\hline & & SPAle & $53.0 \mathrm{a}$ & 4.8 & 2.3 \\
\hline & \multirow[t]{4}{*}{ July plant height (mm) } & ATCAe & 207.4 ba & 13.6 & 1.4 \\
\hline & & BOERe & 184.6 bc & 13.5 & 1.2 \\
\hline & & Control & $149.9 \mathrm{c}$ & 14.1 & 1.0 \\
\hline & & SPAle & $237.8 \mathrm{a}$ & 13.4 & 1.6 \\
\hline & \multirow[t]{4}{*}{ October crown diameter $(\mathrm{mm})$} & ATCAe & $0.5 \mathrm{~b}$ & 0.1 & 1.1 \\
\hline & & BOERe & $0.6 \mathrm{ba}$ & 0.1 & 1.4 \\
\hline & & Control & $0.4 \mathrm{~b}$ & 0.1 & 1.0 \\
\hline & & SPAle & $0.7 \mathrm{a}$ & 0.1 & 1.6 \\
\hline & \multirow[t]{4}{*}{ October plant height (mm) } & ATCAe & $4.0 \mathrm{a}$ & 0.2 & 1.3 \\
\hline & & BOERe & $3.8 \mathrm{ba}$ & 0.2 & 1.2 \\
\hline & & Control & $3.2 \mathrm{~b}$ & 0.2 & 1.0 \\
\hline & & SPAle & $3.8 \mathrm{ba}$ & 0.2 & 1.2 \\
\hline & \multirow[t]{4}{*}{ Harvested seed $(\mathrm{g})$} & ATCAe & $43.0 \mathrm{a}$ & 5.4 & 5.9 \\
\hline & & BOERe & 29.1 ba & 5.4 & 4.0 \\
\hline & & Control & $7.3 \mathrm{c}$ & 5.4 & 1.0 \\
\hline & & SPAle & $21.8 \mathrm{bc}$ & 5.4 & 3.0 \\
\hline & \multirow[t]{4}{*}{ Average aboveground biomass $\left(g \cdot\right.$ plant $\left.^{-1}\right)$} & ATCAe & $20.3 \mathrm{a}$ & 2.6 & 3.0 \\
\hline & & BOERe & $18.8 \mathrm{a}$ & 2.6 & 2.7 \\
\hline & & Control & $6.9 \mathrm{~b}$ & 39.3 & 1.0 \\
\hline & & SPAle & $22.5 \mathrm{a}$ & 39.3 & 3.3 \\
\hline
\end{tabular}

${ }^{1}$ Different letters next to an estimate indicate statistically significant differences between estimates within a column for each variable at $\alpha=0.05$. 


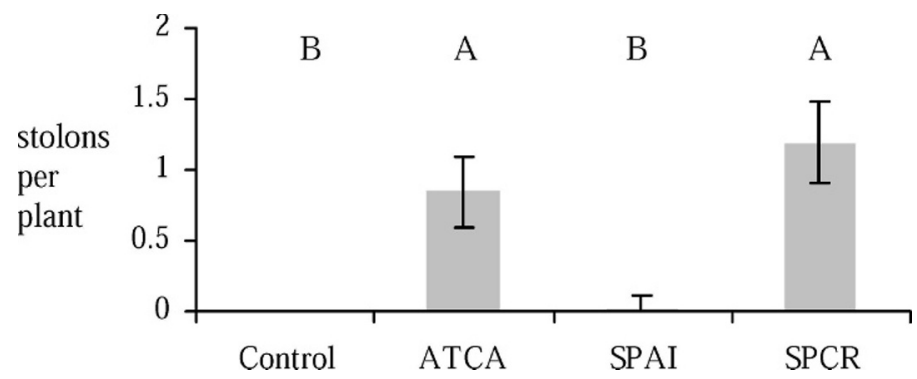

Figure 2. Estimate of the mean number of stolons present on black grama plants $5 \mathrm{mo}$ after transplanting. Error bars represent standard error of the mean. Means with different letters are significantly different. $(\mathrm{F}=2.70, P=0.05)$.

An alternative explanation for enhanced growth following cocultivation could be that natural hormones from the donor calli are influencing early plant growth. Although this hypothesis cannot yet be ruled out, we believe the endophytetransfer hypothesis seems more probable at this time. Literature describing endophyte-enhanced growth of diverse plants worldwide is common (Clement et al. 1997; Narisawa et al. 2000; Schulz et al. 2002; Narisawa et al. 2004; Rudgers et al. 2004; Schardl et al. 2004; Waller et al. 2005), and the persistance of black grama and fourwing saltbush endophytes in vitro throughout the plant regeneration process suggests an evolutionary dependence (Barrow et al. 2004). Although the evolutionary significance of endophyte interactions in plant evolution remains debated, it is clear that endophytes can influence host fitness (Waller et al. 2005).

It has been suggested that tens to hundreds of endophyte species may exist in natural settings (Vandenkoornhuyse et al. 2002; Ganley et al. 2004). This diversity of endophytes in native plants may represent an underutilized resource with potential to develop hardier grass and forage germplasms. Because soil and plant surface (epiphytic) microbes are well adapted to growth in the external environment, we speculate that these species restrict the ability of endophytic fungi to colonize new hosts in natural settings. Therefore, we suspect endophyte transfer in nature is rare.

\section{IMPLICATIONS}

This investigation suggests that cocultivation of grasses with alternate species may profoundly influence whole plant biomass, seed and stolon production, and plant mortality. Although these results are promising, it is important to recognize that much work remains before findings can be applied beyond research environments. First, these results need to be verified by additional trials, especially trials under more natural rangeland conditions. Second, even if endophyte transfer proves to be responsible for the observed impacts, it is important to recognize that many aspects of endophyte biology are unknown. Livestock poisonings from toxinproducing endophytes associated with fescues (Schardl et al. 2004) and locoweeds (Braun et al. 2003; McLain-Romero et al. 2004) demonstrate one mechanism by which endophytes that enhance plant productivity might negatively impact broader-scale ecosystem processes. Therefore, we advise cautious monitoring of endophyte-modified vegetation from multiple perspectives so that both benefits and potential hazards can be examined.

Perhaps the most prudent immediate response to this research is to recognize one more reason why maintaining plant diversity may be beneficial. Even plants that are undesirable as forage may assist surrounding species by hosting valuable endophytes or producing natural products that facilitate growth of neighboring species.

\section{LITERATURE CITED}

Association of Official Seed Analysts. 1990. Rules for testing seeds. Bozeman, MT, USA: Association of Official Seed Analysts. $122 \mathrm{p}$.

Barrow, J., M. Lucero, I. Reyes-Vera, and K. Havstad. 2007. Endosymbiotic fungi structurally integrated with leaves reveals a lichenous condition of $\mathrm{C} 4$ grasses. In Vitro Cellular \& Developmental Biology—Plant 43:65-70.

Barrow, J. R., and P. Osuna. 2002. Phosphorus solubilization and uptake by dark septate fungi in fourwing saltbush, Atriplex canescens (Pursh) Nutt. Journal of Arid Environments 51:449-459.

Barrow, J. R., P. Osuna-Avila, and I. Reyes-Vera. 2004. Fungal endophytes intrinsically associated with micropropagated plants regenerated from native Bouteloua eriopoda Torr. and Atriplex canescens (Pursh) Nutt. In Vitro Cellular \& Developmental Biology_Plant 40:608-612.

Braun, K., J. Romero, C. Liddell, and R. Creamer. 2003. Production of swainsonine by fungal endophytes of locoweed. Mycological Research 107:980.

Bultman, T., And G. Bell. 2003. Interaction between fungal endophytes and environmental stressors influences plant resistance to insects. Oikos 103:182-190.

Clay, K., T. N. Hardy, and A. M. Hammond. 1985. Fungal endophytes of grasses and their effects on an insect herbivore. Oecologia 66:1-5.

Clay, K., J. HOLAH, AND J. A. Rudgers. 2005. Herbivores cause a rapid increase in hereditary symbiosis and alter plant community composition. Proceedings of the National Academy of Sciences of the United States of America 102:1246512470.

Clay, K., And C. Schardl. 2002. Evolutionary origins and ecological consequences of endophyte symbiosis with grasses. American Naturalist 160:S99-S127.

Clement, S. L., A. D. Wilson, D. G. Lester, and C. M. Davitt. 1997. Fungal endophytes of wild barley and their effects on Diuraphis noxia population development. Entomologia Experimentalis et Applicata 82:275-281.

Ellis, R. H., T. D. Hong, and E. H. Roberts. 1985. Compendium of specific germination information and test recommendations Vol II. Handbook of seed technology for genebanks No. 3. Rome, Italy: International Board for Plant Genetic Resources. 465 p.

Ernst, M., K. W. Mendgen, and S. G. R. Wirsel. 2003. Endophytic fungal mutualists: seed-borne Stagonospora spp. enhance reed biomass production in axenic microcosms. Molecular Plant-Microbe Interactions 16:580-587.

Ganley, R. J., S. J. Burunsfeld, and G. Newcombe. 2004. A community of unknown, endophytic fungi in western white pine. Proceedings of the National Academy of Sciences of the United States of America 101:10107-10112.

Govindarajulu, M., P. E. Pfeffer, H. R. Jin, J. Abubaker, D. D. Douds, J. W. Allen, H. Bucking, P. J. Lammers, and Y. Shachar-Hill. 2005. Nitrogen transfer in the arbuscular mycorrhizal symbiosis. Nature 435:819-823.

Lucero, M. E., J. R. Barrow, P. Osuna, And I. Reyes. 2006. Plant-fungal interactions in arid and semiarid ecosystems: large-scale impacts from microscale processes. Journal of Arid Environments 65:276-284.

Mclain-Romero, J., R. Creamer, H. Zepeda, J. Strickland, and G. Bell. 2004. The toxicosis of Embellisia fungi from locoweed (Oxytropis lamberti) is similar to locoweed toxicosis in rats. Journal of Animal Science 82:2169-2174.

Murashige, T., and F. Skoog. 1962. A revised medium for rapid growth and bioassays with tobacco tissue cultures. Physiologia Plantarum 15:473-497.

Narisawa, K., K. T. OhKI, and T. Hashiba. 2000. Suppression of clubroot and Verticillium yellows in Chinese cabbage in the field by the root endophytic fungus, Heteroconium chaetospira. Plant Pathology 49:141-146. 
Narisawa, K., F. Usuki, and T. Hashiba. 2004. Control of Verticillium yellows in Chinese cabbage by the dark septate endophytic fungus LtVB3. Phytopathology 94:412-418.

Obledo, E., L. Barragan-Barragan, P. Gutierrez-Gonzalez, B. Ramirez-Hernandez, J. Ramirez, and B. Rodriguez-Garay. 2003. Increased photosyntethic efficiency generated by fungal symbiosis in Agave victoria-reginae. Plant Cell Tissue and Organ Culture 74:237-241.

Pirttila, A., H. Pospiech, H. Laukkanen, R. Myllyla, and A. Hohtola. 2003. Two endophytic fungi in different tissues of Scots pine buds (Pinus sylvestris L.). Microbial Ecology 45:53-62.

Redman, R., K. Sheehan, R. Stout, R. Rodriguez, and J. Henson. 2002. Thermotolerance generated by plant/fungal symbiosis. Science $298: 1581-1581$.

Rudgers, J. A., J. M. Koslow, and K. Clay. 2004. Endophytic fungi alter relationships between diversity and ecosystem properties. Ecology Letters 7:42-51.

SAS InSTITUTE [computer program]. 2003. Statistical Analysis Software for Windows. Version 9.1.3. Cary, NC, USA: SAS Institute, Inc.
Schardl, C. L., A. Leuchtmann, and J. J. Spiering. 2004. Symbioses of grasses with seedborne fungal endophytes. Annual Review of Plant Biology 55:315-340.

SCHEINER, S. M. 1993. Introduction: theories, hypotheses, and statistics. In: S. M. Scheiner and J. Gurevitch [EDS.]. Design and analysis of ecological experiments. New York, NY, USA: Chapman and Hall. p. 1-13.

Schulz, B., C. Boyle, S. Draeger, A. K. Rommert, and K. Krohn. 2002. Endophytic fungi: a source of novel biologically active secondary metabolites. Mycological Research 106:996-1004.

Vandenkoornhuyse, P., S. L. Baldauf, C. Leyval, J. Straczek, and J. P. W. Young. 2002. Evolution: extensive fungal diversity in plant roots. Science 295:20512051.

Waller, F., B. Achatz, H. Baltruschat, J. Fodor, K. Becker, M. Fischer, T. Heier, R. Huckelhoven, C. Neumann, D. von Wettstein, P. Franken, and K. H. Kogel. 2005. The endophytic fungus Piriformospora indica reprograms barley to saltstress tolerance, disease resistance, and higher yield. Proceedings of the National Academy of Sciences of the United States of America 102:13386-13391. 